\title{
Medisinen er ikke politisk nøytral
}

«Helsetjenesteaksjonen setter ord på mye frustrasjon blant helsepersonell, men kan bidra til at vi får mer av det vi minst ønsker,» skrev Steinar Westin i Aftenposten nylig (1). Helsetjenesteaksjonen oppfattet at Westin mente at de støttet bestemte politiske partier og klargjorde i innlegg både i VG og Aftenposten at de var partipolitisk nøytrale og mente at ingen av dagens store politiske partier hadde gode løsninger $(2,3)$ : «Helsetjenesteaksjonen står for den andre veien, en helsetjeneste der pasientomsorg og faglige verdier er viktigst. Vi krever en ny helsepolitikk fra alle partier.»

Helsetjenesteaksjonen skriver at industriens driftsmodeller ikke passer for helse, omsorg og pleie, at det burde være plass i sykehus og sykehjem til alle som trenger det og at fagfolkene må få gjøre jobben sin og ikke bruke arbeidstiden til dyrt og meningsløst byråkrati (2). Det er lett å være enig i det. Men hvordan få det til? Man kan nesten få inntrykk av at dersom det bare bevilges nok penger og sjekken sendes til fagmiljøene, vil resten ordne seg. Men slik er det jo ikke.

For hva er faglige verdier, og hvilke fagfolk skal bestemme hva som er korrekt bruk av pengene? Det er det mange meninger om. Innen de aller fleste fagmiljøer er det stor uenighet om selv nokså enkle og entydige problemstillinger, jf. debatten om korrekt antibiotikabehandling her i Tidsskriftet nylig. Enda større diskusjon om hva som er faglig korrekt blir det når pasientgrupper må veies opp mot hverandre. Og det er ytterst vanskelig å bli enige om etiske verdier, for eksempel om det er riktigere å gi et maksimalt tilbud til den pasienten du har foran deg og glemme de pasientene du ikke ser, enn å fordele ressursene på flere selv om det betyr at tilbudet til hver enkelt må begrenses.

Å late som det er ubegrensede ressurser eller at det gå an å bevilge seg ut av dilemmaene, er å stikke hodet i sanden. En vesentlig grunn til dette er at helsetjenesten ikke er som andre tjenester. Ikke fordi tjenestene er så spesielle, men fordi helsemarkedet fungerer dårlig.

Enkelt sagt fungerer markedstankegang dårlig for helsetjenesten som helhet, men kan virke utmerket for mange enkelttjenester. Hvor godt det kan fungere vet alle vi (og det er mange av oss) som noen gang har benyttet oss av private helsetjenester. Vi er villige til å betale for dem nettopp fordi de er gode nok og mer tilgjengelige enn det tilbudet vi kan få nesten gratis fra det offentlige. Når jeg har behov for en konsultasjon hos fastlegen, en gynekologisk undersøkelse, en hofteoperasjon, et opphold på psykiatrisk institusjon, hjemmesykepleie eller for den saks skyld en avansert og kostbar kreftbehandling, har jeg ingen store problemer med å betrakte dette som tjenester jeg kan tenke meg å kjøpe.
Det er altså ikke tjenestenes art som er problemet, men at markedsmekanismene ikke fungerer. Det er mange grunner til det, men sterkt forenklet er sammenhengen denne: Et velfungerende marked fordrer symmetrisk informasjon, dvs. at den som tilbyr og den som etterspør en vare eller tjeneste vet omtrent det samme. Kunden må være rimelig sikker på hva man kjøper for å kunne avgjøre hva som er riktig pris. Disse forutsetningene er langt fra oppfylt for helsetjenester: Helsepersonell - særlig leger - har langt mer informasjon enn pasientene om det diagnostiske og behandlingsmessige tilbudet. Og den som kjøper en tjeneste (pasienten), er på ingen måte garantert et bestemt utfall. Pasienten velger heller ikke å bli syk og kommer i et spesielt avhengighetsforhold til dem som tilbyr helsetjenester. Dermed styres «markedet» i stor grad av tilbyderne - altså helsepersonell. Det er dette vi kaller tilbudsstyrt etterspørsel. Når det i tillegg er slik at det stort sett er en tredje part, i Norge staten, som betaler regningen, finnes det få incentiver til å holde prisen på tjenestene nede for dem som tilbyr (legene) og dem som etterspør (pasientene). Dette er en viktig grunn til at kostnadsveksten i helsevesenet er så vanskelig å kontrollere. Et helt fritt marked vil heller ikke være i stand til å tilfredsstille en rekke andre viktige hensyn og ønsker, for eksempel jevn fordeling. Men det kan løses med ulike former for reguleringer.

«Politikerne må ta ansvar for å definere rammebetingelser for helsetjenesten,» skriver Helsetjenesteaksjonen på sine hjemmesider. Ja, naturligvis. Men rammebetingelser betyr ikke bare størrelsen på økonomiske bevilgninger. Det betyr kommunegrenser, samferdselspolitikk og selvsagt arbeidsmarkedspolitikk og mye mer. For å sette det litt på spissen: Den aller raskeste og mest effektive måten å frigjøre ressurser til pasientbehandling på, er å ta fra midlene som går til de friske (altså lønn til helsepersonell) og bruke det på de syke.

Den klart største utfordringen i helsepolitikken er å få kontroll på den offentlige kostnadsveksten uten at tilbudet innskrenkes. Det kan i hovedsak gjøres på to måter - (enda) hardere styring av tilbudet som gis eller privatisering av (deler av) betalingen. Det er dette Steinar Westin sikter til når han skriver at vi ved dette stortingsvalget står ved et veiskille (1). Ingen av veiene er behagelige. Ingen av veiene er ideelle. Men det må velges. Velger man å ikke ta stilling, gir man sin stemme til det alternativet man minst foretrekker, for medisinsk virksomhet er ikke politisk nøytral.

\footnotetext{
Litteratur

1. Westin S. Et veiskille for helsetjenesten. Aftenposten 19.8.2013.

2. Halvorsen M, Wyller TB. Hvem truer den offentlige helsetjenesten? Aftenposten 21.8.2013.

3. Aakre M. Wyller TB. Ap og Høyre i helsepolitisk tospann. VG 22.8.2013.
} 